\title{
マイクロ波による澱粉の殺菌効果
}

\author{
柳井昭二* 山田康郎** 木村 進*
}

(昭和 47 年 10 月 16 日受理)

\section{Effect of Microwaves on the Bacterial Counts of Starch}

Shoji YANAI*, Yasuro YamadA** and Susumu KImURA*

* National Food Research Institute, Ministry of Agriculture and Forestry

**Hokkaido Industrial Research Institute

\begin{abstract}
Bacterial disinfestation in the microwave treatment of starch was determined:
(1) The microwave treatment of starch for the period of three minutes reduced the viable count of the starch samples to the extent of $37-75 \%$.

(2) When the moisture content of starch was increased from $16.5 \%$ to $26 \%$, disinfestation effect of the microwaves was enhanced, although partial gelatinization of the starch occurred after two minutes.

(3) The resistance of thermophiles isolated from starch samples was tested in water with microwave treatment. The susceptibility of the isolates to the microwave treatment was similar to that to heat treatment, the survival was, however, greater with the latter than with the former.
\end{abstract}

マイクロ波誘電加熱の食品の処理, 加工への利用は, 電子レンジの普及が始まってから，急速な温度上昇にそ の価值が認められ，その利用面の開発1が広く行なわれ ている。マイクロ波による食品の殺菌効果については, 各種の食品について試験され2 7)ているが，まだ知られ ていない点が多い。

近年食品工業においては, 生菌数の少ない原料を要求 することが多くなっている。食品素材として大きな地位 を占めている澱粉は製造法の合理化から生菌数も少なく なっているがまだ満足される状態ではなく，適当な殺菌 方法の確立が要望されている。そこで，澱粉に対するマ イクロ波殺菌の可能性を検討するために本実験を行なっ た。

\section{実 験 方 法}

\section{1. 試 料}

合理化工場の馬鈴薯澱粉（水分 $17.7 \%$ ） と在来法工 場の甘譇測粉（水分 $16.5 \%$ ）を試料とした。

* 農林省食品綜合研究所（東京都江東区塩浜）

** 北海道立工業試験場（札幌市琴似八軒 1 条西 3 丁目)

\section{2. マイクロ波照射方法}

シャープ Micro-range（周波数 $2450 \mathrm{MHz}$, 出力 0.6

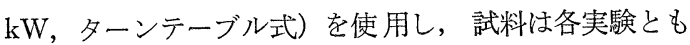
$5 \mathrm{~g}$ を科取し, 径 $40 \mathrm{~mm}$ のシャーレに平らに入れ（厚 さ約 $8 \mathrm{~mm}$ ), 電子レンジのターンテーブル上の中心より 約 $6.0 \mathrm{~cm}$ のところに内側の端を合わせて置き，それに 対称の位置に $300 \mathrm{~m} l$ ビーカーに水 $100 \mathrm{~m} l$ を入れ各実 験時間照射した。

\section{3. 生菌数の測定}

Plate count 培地を使用し, $30^{\circ} \mathrm{C} 48$ 時間培養後計数 した。稀釈その他の操作は常法によったが, 試料の䀣濁 状態を良くするため, 稀釈には滅菌 $0.1 \%$ 寒天溶液を 使用した。

\section{4. 試料の水分測定}

アルミ製科量皿を用い， $135^{\circ} \mathrm{C} 1$ 時間の常圧乾燥法に よって測定した。

\section{実 験 結 果}

\section{1. マイクロ波照射時間と殺菌効果}

試料の照射時間は 30 秒から 180 秒の間で 4 段階につ いて行ない, 各照射時間について, 試料の水分, 生菌数 


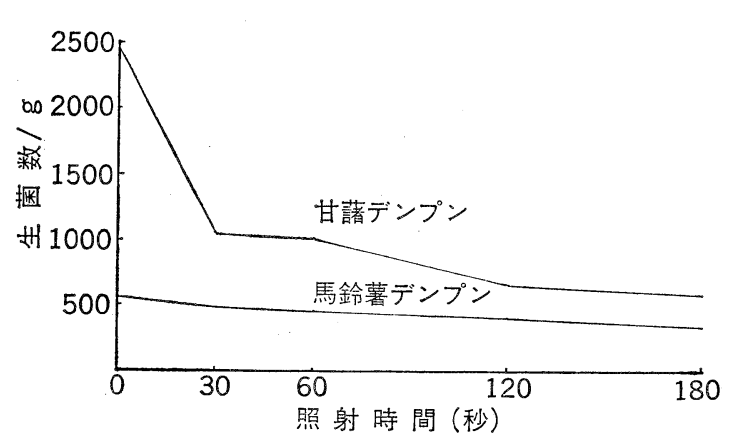

図1 甘榙澱粉と馬鉿薯澱粉のマイク口波による殺菌効果

を測定した。結果は図 1 のおりである。甘藷港粉およ び馬鈴䕒澱粉の生菌数は, それぞれ $\mathrm{g}$ 当り, $2.4 \times 10^{3}$, $5.6 \times 10^{2}$ であったが， 3 分間照射処理後では，それぞれ $24.3 \%, 62.5 \%$ の生残率を示し, 大きな殺菌効果は得 られなかった。一方照射中の試料の水分蒸発量注きく 表 1 に示すごとく, 3 分閒で約 $65 \%$ の水分が失われた。

\section{2. 澱粉の水分量と殺菌効果}

澱粉の含水量が殺菌効果にどの程度影響するかを検討 するために，殺菌水とシリカゲルデシケーターで吸湿お よび失湿甘諳澱粉を調整し, 照射時間による水分蒸発, 生菌数の減少を比較した。結果は図 2 亿示した。水分蒸 発については, $26 \%$ および $16 \%$ 水分含有試料では同 じ程度の乾燥程度を示すが, $7 \%$ の乾燥試料で泣, それ ほど水分の低下は示さない。生菌数は, 予想されたごと く水分が多いほど殺菌効果が高く, 高水分試料で約 $11 \%$, 低水分試料で約 $37 \%$ の細菌が生残した。しかしいずれ の場合でも, 細菌学的には大きな殺菌効果とはいえずこ れ以上の殺菌は, 澱粉の場合困難のように考穴られる。 即ち, 高水分試料では 2 分閒照射で糊化部分が生じこれ 以上の照射は品質上から無理であるように思われた。

\section{3. 乾熱による殺菌効果}

マイクロ波照射と乾熱による加熱での殺菌効果はとく にその時間的比較を見るために，ロータリ一式定温乾燥 器を用い $105^{\circ} \mathrm{C}$ で実験した。試料はマイクロ波照射と 同様 $5 \mathrm{~g}$ をシャーレに入れて各時間加熱した。温度そ の他比較の基準が得にくいため, いちおう水分減少量を 基準として加熱時間を， 5, 10,20, 30 分の 4 段階とした。 結果は図 3 に示した。単純に比較すると水分蒸発速度は,

表 1. 照射時間と激粉水分量の変化

\begin{tabular}{c|ccccc}
\hline 照射時間(秒) & 0 & 30 & 60 & 120 & 180 \\
\hline 水分 $(\%)$ & 16.5 & 15.9 & 13.2 & 10.4 & 5.8 \\
\hline
\end{tabular}

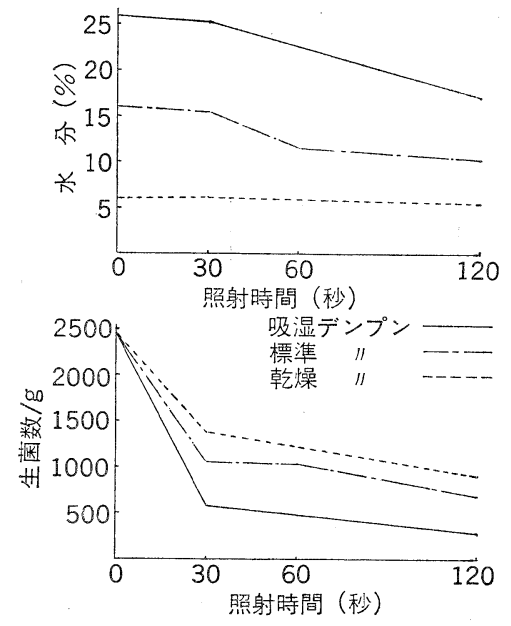

図 2 澱粉の含水量と照射効果

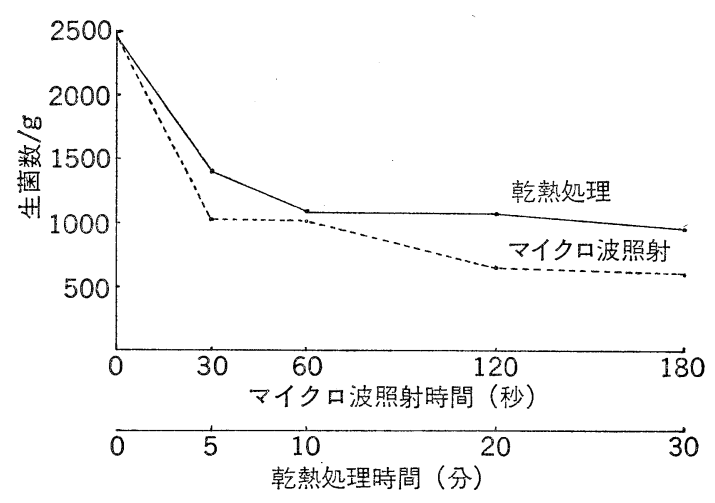

図 3. 乾熱処理とマイクロ波照射との殺菌効 果の比較

マイクロ波に対し乾熱で約 10 倍の時間を要し, 生菌数 の減少速度では $1 / 10$ 以下ということになる。

\section{4. 分離耐熱性細菌のマイクロ波および加熱による殺菌}

$90^{\circ} \mathrm{C} 10$ 分間の熱処理によって試料中より分離した耐 熱性細菌 3 株を選び実験に供試した。前培養により胞子 を形成させたスラントから 1 白金耳とり $100 \mathrm{~m} l$ の滅菌 水に懸濁させ, 各 $3 \mathrm{~m} l$ 滅菌試験管にとって, マイクロ 波を照射し, 加熱の場合は沸騰水中に浸してそれぞれの 時間加熱した。処理後全液を平板培養してコロニー数を 計数した。結果注 2 および表 3 に示した。供試菌株の マイクロ波に対する抵抗性は, 菌株 $\mathrm{A}>\mathrm{C}>\mathrm{B}$ の順に つよく, 加熱の場合も同様である。いずれにしても供試 菌株の懸濁液の場合は, マイクロ波で 2 分間, 加熱処理 では, $100^{\circ} \mathrm{C} 10$ 分間で殺菌が可能であった。 
表 2. マイクロ波照射に対する耐熱性細菌の抵抗性

\begin{tabular}{|c|c|c|c|c|c|c|}
\hline $\begin{array}{c}\text { 照射時間 } \\
\text { (秒) }\end{array}$ & 0 & 15 & 30 & 60 & 90 & 120 \\
\hline 菌株 A & $5.5 \times 10^{4}$ & $+^{*}$ & + & 20 & 5 & 0 \\
\hline 菌株 B & $3.2 \times 10^{4}$ & + & 4 & 0 & 0 & 0 \\
\hline 菌株 C & $1.6 \times 10^{4}$ & + & 73 & 0 & 0 & 0 \\
\hline
\end{tabular}

$* \sqsupset ロ=-$ 数計数不能.

表 3. 沸騰水中における耐熱性細菌の抵抗性

\begin{tabular}{|c|c|c|c|c|c|}
\hline $\begin{array}{c}\text { 加熱処理時間 } \\
\text { (分) }\end{array}$ & 0 & 1 & 3 & 5 & 10 \\
\hline 菌株 & $8.7 \times 10^{4}$ & $+*$ & 59 & 7 & 0 \\
\hline 菌株 B & $7.7 \times 10^{4}$ & 24 & 0 & 0 & 0 \\
\hline 菌株 C & $2.0 \times 10^{5}$ & + & 2 & 0 & 0 \\
\hline
\end{tabular}

* コロ = - 数計数不能.

\section{考察}

実験 1，2 および 4 の結果から，澱粉のような比較的 含有水分の低、試料では，マイク口波殺菌は効果が少な く，理論的な考えと一致するところである。水分を増加 させて殺菌効果を上げることは，ある程度可能である が，澱粉の場合は熱による糊化現象等の問題がからみ， 飛躍的な殺菌効果注実際上困難である。実験 1 亿抒い て，馬鈴薯澱粉に比して，甘藷潵粉のほうが生残率が低 く, 生菌数の多い方が殺菌効果があるように考えられる が，この場合は，むしろ試料中の細菌フロラの差異が大 きな要素であると考える。このことは，実験 4 の結果か らもらかがえるところであり，試料中に存在する菌の耐 熱性等に差がある場合には菌数のみでは速断できない。 したがって一定の既知菌種を使用してのモデル実験が必 要である。

マイクロ波による殺菌効果が，急速に上昇する熱のみ によるものか，その他なんらかの効果が劺いているかと いう点については，まだ明確ではないが，赤星8)による と強いマイクロ波電場の作用のため細胞の蛋白，生理活 性物質の変性が扔こって殺菌が促進されると述べてい
る。また最近 GOLDBLITH らは993水を用い, LECHOWICH らは10)特殊な装置を用いてマイクロ波照射による殺菌効 果は単なる熱エネルギーによることを報告している。実 験 3 および 4 で細菌のマイク口波に対する抵抗が熱に対 する抵抗と同一の傾向を示すことは，LECHOWICH らの 実験を裏付けるものと考えられる。

澱粉を原料として加工食品を製造する際に，原料澱粉 のマイクロ波殺菌の効果は，水分含量の点から期待し得 ないが，各種の原料配合時に加水する場合には，照射效 果も期待されるものと思われる。

\section{要約}

マイクロ波照射による澱粉の殺菌効果について検討し 次のような結果を得た。

（1） 3 分間のマイクロ波照射により，澱粉の生菌数 は約 $37 \%$ から $75 \%$ 程度減少した。

（2）激粉の水分含量を $16.5 \%$ から $26 \%$ に増加 させて照射すれば殺菌効果は高くなるが，2 分間照射で 糊化部分が生ずる。

（3）分離した耐熱性細菌の水溶液中でのマイク口波 に対する抵抗性は，単純な加熱殺菌の場合々同様に，菌 株間で同一の傾向定示すが，時間的にはマイクロ波の方 が早く死滅する。

\section{引用 文 献}

1) S. A. Goldblith : Advan. Food Res., 15, 277 (1966).

2) C. M. Olsen: Food Eng., 37, 51 (1965).

3) J. Manwaring: Food Eng., 38, 48 (1966).

4）露木英男，首藤 厚：食品工業，10，52 (1967).

5）佐々木正：食品工業，10，28（1967）。

6）酒井宏美：第2回食品包装研究協議会資料, 22 (1968).

7）古泉快夫，佐藤正子，武 桓子，大塚一止：食品工 誌， 14， 545 (1967).

8）赤星亮一：日本食品工業学会第 12 回大会講演集, 94 (1965).

9) S. A. Goldblith, D. I. C. WANG: Appl. Microbiol., 15, 1371 (1967).

10) R. V. Lechowich, L. R. Beuchat, K. I. Fox, F. H Webster: Appl. Microbiol., 17, 106 (1969). 